\title{
Modes of Discourse: A Cross- Cultural Study of Essays Written in English and Spanish by EFL Students in Costa Rica (Part I)
}

lleana Saborío Pérez ${ }^{1}$

Universidad Nacional, Costa Rica

\section{RESUMEN}

Mediante un análisis contrastivo se evalúan los patrones retóricos interculturales desarrollados por estudiantes nativohablantes del español, en el proceso de escritura. Se plantean cinco preguntas de investigación con respecto a las diferencias o similitudes cuando se escribe en español o en inglés, y su influencia en la escritura para el desarrollo del estilo y la estructura oracional, así como sus implicaciones pedagógicas.

\section{Abstract}

A contrastive analysis was used to evaluate the cross-cultural rhetorical patterns developed by native Spanish-speaking students, in the writing process. Five research questions were posed with respect to similarities or differences when writing in Spanish or English, and their influence on writing in the development of style and sentence structure, as well as their pedagogical implications.

Palabras claves: expresión escrita, análisis contrastivo, lengua y cultura Keywords: writing, contrastive analysis, language and culture

$\overline{1}$ Correo electrónico: isaborio@una.ac.cr. 
Writing in one's native language is a difficult skill to develop. It is even more difficult to write in a foreign language whose instructional processes are quite different. Most research in this area of language teaching has been devoted to problems of syntax, vocabulary, and mechanics. Numerous studies across languages on textual organization have provided evidence on differences in how learners write in a foreign language and on the influence that the native language has upon the target language. Although a great deal of research has been carried out on expository discourse, at the time this study was carried out few studies had been dedicated to analyzing other genres except for those of Soter on narrative ${ }^{2}$ Connor $^{3}$ on the argumentative mode of discourse, and Connor and Talaka ${ }^{4}$ also on argumentative discourse. Of particular interest here is the research conducted by Rodino and Ross on the writing of Costa Rican university students. ${ }^{5}$ In Problemas de expresión escrita del estudiante universitario costarricense, they suggest that if students have difficulty developing an essay in chronological order, it will be even greater in the case of more complex and abstract discourse which requires the definition of concepts and the development of argumentation. Based on these premises, on the pedagogical implications that they have, and on the fact that a study of this nature had not been carried out in Costa Rica, the researcher considered them valid reasons to investigate this phenomenon. Subsequent studies have shown that contrastive rhetoric is indeed useful for the development of writing competence. ${ }^{6}$

$2 \quad$ Anna O. Soter, "The Second Language Learner and Cultural Transfer in Narration," Writing across Languages and Cultures: Issues in Contrastive Rhetoric, ed. Alan Purves (Newbury Park, CA: Sage Publications, 1988) 177-205.

Ulla Connor \& Robert B. Kaplan, eds., Writing across Languages: Analysis of L2 Text (Reading, Mass: Addison-Wesley Publishing Company, 1987).

Ulla Connor. "Argumentative Patterns in Student Essays: Cross-Cultural Differences," Writing across Languages: Analysis of L2 Text, eds. U. Connor and R. B. Kaplan (Reading, Mass: Addison-Wesley, 1987) 57-72.

3. Ana María Rodino \& Ronald Ross, Problemas de expresión escrita del estudiante universitario costarricense (San José, Costa Rica: EUNED, 1985) 156.

Pablo Deza Blanco, "Tres décadas de Retórica Contrastiva español-inglés: un poderoso instrumento para mejorar la competencia discursiva escrita de los estudiantes de ELE," Revista 
The English Department of the Universidad Nacional (Costa Rica) offers an intensive English program that prepares students to be proficient in that language as well as to teach it. An essential part of this program is to train students to be competent in their writing skills, to which end they have to take a series of writing courses to accomplish their academic requirement. Based on the researcher's experiences in teaching these courses, it is common to observe a series of problems that the students have regarding mechanics, patterns of organization, language use, vocabulary, and content. The causes of these problems have been stated informally elsewhere. However, of the problems mentioned above, rhetorical components and patterns of organization (or more specifically, the argumentative mode of discourse) are two particular areas that need to be studied carefully.

The argumentative pattern is one of the modes that causes the most difficulties in foreign language learners, and is one of the kinds of writing that is not taught in the Spanish language arts program in high school composition courses, as established by the Ministry of Education in Costa Rica. What makes this learning situation more problematic is that the students also show difficulties when writing in Spanish. According to Rodino and Ross, ${ }^{7}$ beginning university students in Costa Rica have been shown not to write well in Spanish. In their study, the results of analysis of texts with regard to patterns of development of chronological order were disappointing. When some of these students study English as a foreign language and start developing patterns of English writing, they face not only a new language structure, but also a potential cross-cultural interference problem from their native language. This assumption is supported by the hypothesis on contrastive rhetoric.

\footnotetext{
de didáctica (2006), accessed March 13, 2007. <http://www.marcoele.com/num/3/ 0218f 5989f0037105/retoricacontrastiva.pdf $>$. The value of the present article, however, is that it is devoted to the particular case of Costa Rica, which has not varied significantly in the interim.

$7 \quad$ Rodino and Ross, 1.
} 
The contrastive rhetoric hypothesis does not imply that speakers of different linguistic backgrounds think differently; the point is to discover from all the diverse problems that the learners have what the potential interference problems are. This has pedagogical implications in making writing teachers of a foreign language aware of the diverse types of problems that the students might have, and therefore, of the different kinds of solutions available to the teacher, depending on the learner's linguistic background.

To this end, an investigation was carried out on cross-cultural rhetorical patterns (patterns of development, specifically the argumentative mode) developed by Spanish speakers writing in English.

The research question orienting this investigation was: What are the students' main problems when writing in English using the argumentative mode?

As part of the study, four additional research questions were included:

1. Did Costa Rican university students learn to write in Spanish the same way they do in English? If not, how is the process different?

2. Are there differences in modes of discourse between the way these students write in English or in Spanish? If so, what are these differences?

3. How much is transfer likely to affect style and sentence-level structure, rather than modes of discourse?

4. What pedagogical implications might be considered based on these findings?

The hypothesis of this study is that there are differences between Spanish writing and English writing instruction in modes of discourse, and that there is an influence from the rhetorical patterns of the students' native language on the rhetorical patterns of their written English. To carry out this cross-sectional primary research, the main 
human source of information was an EFL group composed of twentyone native Spanish speakers. The participants evaluated were students of English as a foreign language in the School of Literature and Language Sciences of the Universidad Nacional (UNA), who were being trained as teachers of EFL.

Data collected in this investigation was used, first of all, to control student variables concerning education, exposure to the target language and native language; academic and personal background was obtained through the administration of a poll. This information included the learning strategies that they used for improving writing skills outside the classroom. Also, their point of view on how they were taught Spanish composition was considered. Then, the instructor responsible for the group was interviewed to find out what she considered to be the main problem in her students' compositions regarding rhetorical patterns and interference problems. Details about approaches, techniques, strategies, and materials used in her classroom werealso asked. Her views on how Spanish composition is taught in Costa Rica versus how English composition is taught were also considered.

To answer the question, "Do Costa Rican students learn to write in Spanish the same way they do in English?", the researcher examined the curriculum for teaching Spanish in high schools established by the Ministry of Education of Costa Rica, as well as that of the UNA English composition courses. Texts and authentic materials used in teaching both language composition processes were also collected and examined. These data were compared and analyzed in order to find the differences or similarities in instruction, content, techniques, approaches, and rhetorical conventions used in both writing processes.

Important data collected in this research were students' essays. First, English compositions were written in a free mode of discourse on a freely chosen topic; a second set of compositions were then collected, but in Spanish. A third set of compositions were written only using the argumentative pattern of development. In this study, an argumentative composition is defined as text in which the writer 
demonstrates in reasoned and logical argument his or her position, belief, or conclusion on a particular subject or topic.

In learning a second or foreign language, students have to cope with their cultural and linguistic backgrounds which may interfere in their oral and written performance. The main theoretical bases for studies in contrastive rhetoric have been founded on the Sapir-Whorf hypothesis. The relationship between language and culture has been investigated as an essential component in teaching a foreign language. Three hypotheses on this linguistic phenomenon have been put forward. One is that the structure of a language determines they way its speakers perceive the world; in this sense, Edward Sapir ${ }^{8}$ argued that there is a relationship between language and culture, and that learners' cultural background will be reflected in their written foreign language because they are completely immersed in social functions and patterns that may not match at all those of the target culture. Sapir's ideas were expanded by his student Benjamin Whorf who claimed that the structure of a language models the speakers' thoughts. This assumption implies that the "culture of a people is reflected in the language that they have employed; because they value certain things done in certain ways, they use their language in ways that reflect what they value and what they do." $\mathrm{A}$ third hypothesis on the influence of native language and culture says that by comparing and contrasting students' native language and culture to the target language and culture, instructors can find and explain some of the difficulties they face in their leaming process.

The investigations described above on language and culture, and on the influence of culture in the writing process when learning a foreign language, are included in the present-day modified Whorfian hypothesis. On the issue of contrastive rhetoric in written discourse, it can be inferred that rhetoric and style are not universal. Culture

\footnotetext{
Edward Sapir, Selected Writings of Edward Sapir in Language, Culture and Personality (Berkeley, CA: University of California Press, 1949).

" Ronald Wardhaugh, An Introduction to Sociolinguistics (Cambridge, Mass.: Basil Blackwell, 1986) 212.
} 
appears to be an integral component of language and thought. Culturespecific rhetorical patterns are reflected in language. Pedagogically, this area of language research seems promising with regard to new teaching perspectives that composition teachers should consider in teaching writing.

In the course of this study, a careful examination was made of syllabuses for Spanish language teaching provided by the Ministry of Education as well as those developed for the teaching of English at the UNA. Materials and texts were also examined. It became clear that Spanish composition instruction was deficient in that only narrative and description modes of discourse were taught without prior preparation or teaching of sentence and paragraph development. Students of Spanish, reading and studying mainly literary texts, were expected to write in a "natural" and naturalistic way in their native language.

In contrast, English composition at the UNA began at the sentence and paragraph level and included nearly all possible modes of discourse, including the argumentative mode (so important for students' scholastic writing responsibilities). Compositions became longer as students' skills increased. Materials included every conceivable type of authentic English text so that students' abilities to handle different modes of discourse would be supported and strengthened by material studied in class work and homework. The short answer to the question is Spanish composition taught differently from English is a resounding yes. To repair the great discrepancies that exist in Spanish composition teaching, Rodino and Ross recommend that the lack of elements presented to students of Spanish composition "can only be provided by establishing a systematic teaching of the language; a teaching that must be profound, analytic, scientifically rigorous, and most of all very active."10 In the teaching of Spanish composition, there is definitely an absence of systematic instruction along with undefined objectives and approaches. ${ }^{11}$

\footnotetext{
10 Rodino and Ross, 19.

$11 \quad$ Rodino and Ross, 1.
} 
Methods and procedures used in the study were as follows: a questionnaire was given to student subjects to become more familiar with their native language proficiency, education level, English proficiency, and exposure to the target environment (in this case, the U.S.A). Second, the students' professor evaluated theirgeneral writing performance. Third, an in-depth interview and questionnaire was given to the professor, in which there appeared more confirmation on the discrepancies between English and Spanish composition instruction. Curricula were compared as well, as described above.

All three sets of compositions produced by the test subjects were assessed and graded by three separate scholars (not their instructor). Essay one was in a free mode of discourse in English, essay two in Spanish in the same mode but on a different topic, and essay three was written only in the argumentative mode in English. Compositions were graded on a modified analytical scale used by the International Association for the Evaluation of Educational Achievement (IEA) Study of Written Composition. A measure of inter-rater reliability was applied to the three evaluators, all trained to evaluate the essays according to principles used in teaching English rhetorical conventions. Two of the raters were Spanish native-speaking EFL instructors, the third an English native-speaking professor in the intensive English program at Ohio University. Complete statistical reliability proofs were applied to all compositions and composition grading throughout (see original thesis, appendices $\mathrm{D}, \mathrm{E}$, and F). ${ }^{12}$

Based on the criteria established for grading the essays on principal content and organization, the researcher analyzed the samples to find answers to the following questions:

a) Are there any differences in the treatment of modes of discourse in the way these students write in English or in Spanish? If so, what are they?

$12 \quad$ Ileana Saborío-Pérez, "Modes of Discourse: A Cross-Cultural Study of Essays Written in English and Spanish by EFL Students in Costa Rica," unpublished thesis (Athens, Ohio: Ohio University, 1991). 
b) What are the students' main problems when writing in the argumentative pattern in English?

The principles of English rhetoric for modes of discourse are what the researcher considers in judging an acceptable essay. As Robert G. Bander (1971) says, "in order to write well in English, a foreign student should first understand how English speakers arrange their ideas. A basic feature of the English paragraph is that it normally follows a straight line of development" (cited by Santana-Seda). ${ }^{13}$

Through the analysis of samples, similarities as well as differences were found in the way students wrote in the diverse modes of discourse in English and Spanish. Among the similarities, it was found that the students generally developed thesis statements in both languages, that most of the development of ideas was grouped into paragraphs, and that specific principles for each mode of discourse seemed to be applied the same way in both languages. On the other hand, some differences were also found regarding organization and style: the development of ideas in Spanish featured "flowery" and unchained sequences of details; in English, the development of ideas followed a straighter line. In the Spanish essays, the students tended to write longer sentences; in the English essays students tended to write shorter sentences. In the Spanish essays, the students' use of transitional words was lower than those in English. The organization of ideas grouped in just one long paragraph occurred more in Spanish essays than in English ones.

Finally, specific problems were found regarding the development of thesis statements, supporting ideas, and the treatment of modes of discourse in both languages; in addition, there was a lack of coherence between paragraphs. These were the most serious in the argumentative essays. In short, students presented problems when writing in all the

$13 \quad$ Olga Santana-Seda, "A Contrastive Study in Rhetoric: An Analysis of the Organization of English and Spanish Paragraphs Written by Native Speakers of Each Language," Ph.D. diss., (New York: New York University, 1974). 
different modes of discourse in both languages, but especially in the argumentative mode.

Based on the results shown from the quantitative data as well as from the qualitative analysis, the research hypothesis is supported in terms of the differences in instruction and in the process followed in English writing and in Spanish writing, and in the degree of transfer from Spanish to English at the level of basic organization and style.

Limitations concerning sample of population, collection of data, and previous research must also be acknowledged in the study. With regard to the collection of data, the researcher could not be present for the essays or for the students' questionnaires. However, she carefully reported the conditions under which the data were gathered. The researcher's objectives were generally achieved, in spite of the difficulties encountered.

At the end of this study a basic question arises: if the contrastive process has been successfully applied at the phonological and syntactic level, why not also contrast both languages at the level of writing as a rhetorical process? As Kaplan insists, "contrastive rhetoric must be taught in the same sense that contrastive grammar is presently taught." 14

Incorporating a contrastive process in the teaching of composition has three principle pedagogical implications. One is that teachers must be aware of how the students' native language is taught and how the rhetorical patterns are different or similar to the way students are taught in the target language. Suggesting the use of contrastive rhetoric in the learning process of writing in a foreign language is a way to make writing teachers aware of the different kinds of knowledge involved when teaching writing. However, teachers must also be aware of the problems students have when writing in their native language. Discovering students' weaknesses in their native language

it Robert Kaplan, "Cultural Thought Patterns in Inter-cultural Education" Language Learning, 16 (1966): 1-20: reprint in Kenneth Croft, ed, Readings on English as a Second Language (Cambridge. Mass.: Winthrop Publishers, 1972) 245-262 (256). 
when writing a paragraph or essay will help the teachers to predict or detect possible problems learners might face when writing in the foreign language. Thus the teacher can help students improve their writing in their native language as well as in the target language, in a kind of positive backward transfer.

One last pedagogical implication applies regarding evaluation. Grading a descriptive composition is not the same as grading an argumentative one. There are different principles involved in the development of each mode of discourse, so teachers must be very careful. Specific guidelines can be incorporated when training teachers how to grade different writing patterns. Here, the scale developed by Jacobs et al. ${ }^{15}$ can be particularly useful. In part II, in another article on this research, these scales will be explained in greater detail and examples will be given on how to use them. The statistical information, based on the results obtained for this research, will also be depicted. It is useful for teachers of a second language to see the breakdown of the statistics for themselves, so that they candecide whether to incorporate the suggestions based on the results of this study in their own teaching of composition in a second language, in this case English.

is H. L. Jacobs et al., Testing ESL Composition: A Practical Approach (Rowley, Mass.: Newbury House, 1981). 